\title{
Iron Status in Pre-Eclampsia: A Case-Comparison Study
}

\author{
R Sultana ${ }^{1}$, S Ahmed $^{2}$, N Sultana ${ }^{3}$, SM Fazlul Karim ${ }^{1}$ \\ ${ }^{1}$ Department of Biochemistry, Delta Medical College, Dhaka; \\ ${ }^{2}$ Department of Biochemistry, Popular Medical College, Dhaka; \\ ${ }^{3}$ Department of Biochemistry, Dhaka Medical College, Dhaka;
}

\begin{abstract}
Preeclampsia is one of the most leading causes of maternal mortality in developing countries. Many studies have demonstrated the relation between alteration of iron status and preeclampsia. The aim of the study was to assess the status of iron in preeclampsia. This case control study was conducted in the Department of Biochemistry, Dhaka Medical College, Dhaka from July 2010 to June 2011. A total number of 100 pregnant women in the third trimester of pregnancy attending the Obstetrics \& Gynaecology Department of Dhaka Medical College Hospital were selected purposively as study subjects. Among them 50 diagnosed cases of preeclampsia were selected as cases and 50 normal healthy pregnant women as controls. Serum ferritin and serum iron concentration were measured in all study subjects. The mean serum ferritin concentration in cases and controls were $95.06 \pm 50.07$ $\mu \mathrm{g} / \mathrm{l}$ and $45.56 \pm 27.44 \mu \mathrm{g} / \mathrm{l}$ respectively. Mean serum iron concentration in cases was $121.78 \pm 41.93 \mu \mathrm{g} / \mathrm{dl}$ and that in controls was $61.04 \pm 24.18 \mu \mathrm{g} / \mathrm{dl}$. The present study showed significant differences of mean serum ferritin and serum iron between cases and controls. The study revealed presence of significantly higher level of serum ferritin and serum iron in preeclamptic group.
\end{abstract}

Key words: Preeclampsia, serum ferritin, serum iro

\section{Introduction}

Preeclampsia is the most serious medical disorder of human pregnancy, which complicates about $5-10 \%$ of pregnancy worldwide $^{1}$. Approximately $10-15 \%$ of maternal mortality in developing countries are associated with preeclampsia ${ }^{2}$. In Bangladesh, the incidence of preeclampsia is alarmingly high, about $16 \%$ of maternal deaths are associated with $\mathrm{it}^{3}$. Preeclampsia is still regarded as 'a disease of theories' and its etiology has remained poorly understood ${ }^{4}$. However, endothelial dysfunction has been considered to play a central role in the pathophysiology of preeclampsia 5 . In many studies alteration of iron status has been claimed as a factor for vascular endothelial cell damage of preeclampsia and its consequences $^{6-8}$. Iron is essential to nearly all cells but the amount of iron required by individual tissues varies during development. At the same time body must protect itself from free iron, which is highly toxic. Its toxicity comes from its propensity to generate free radicals that causes cell damage ${ }^{9}$. Alteration of iron status is related to increased oxidative stress and endothelial dysfunction. Increased oxidative stress is catalysed in presence of free transitional metal ions, particularly iron. Iron or iron species could be a factor in generation of oxidative stress in preeclampsia. Iron species released from ischemic placenta by destruction of red blood cells can initiate the process of lipid peroxidation to cause endothelial cell damage of preeclampsia ${ }^{6}$. In a developing country like Bangladesh, preeclampsia is one of the significant causes of maternal mortality. Therefore, preeclampsia and thereby maternal 
mortality might be reduced through serial monitoring of serum iron status as a part of antenatal check-up. So the present study was designed to assess the status of iron in preeclampsia.

\section{Materials \& Methods}

A case-comparison study was conducted in the Department of Biochemistry, Dhaka Medical College, Dhaka from July 2010 to June 2011. A total number of 100 pregnant women in the third trimester of pregnancy were attending the Obstetrics \& Gynaecology Department of Dhaka Medical College Hospital were selected purposively as study subjects. Among them 50 diagnosed cases of preeclampsia were selected as cases (age range 18 to 35 years) and 50 normal healthy pregnant women as controls (age range 18 to 32 years). Pregnant women with pre-existing hypertension, renal disease, liver disease, diabetes mellitus, some autoimmune diseases and haemoglobin disorder were excluded from the study by history, clinical examination and relevant laboratory investigations. With all aseptic precautions morning fasting blood samples were collected from all the study subjects for estimation of serum ferritin, serum iron concentration. Statistical analysis was performed by using computer based software, Statistical Package for Social Sciences (SPSS) for Windows version 14.0. Mean values of different parameters were compared to determine the differences between two groups by using Student's unpaired' $t$ ' test. For all statistical analysis, two tailed ' $p$ ' value $<0.05$ was considered as a lowest level of significance.

\section{Results}

The study showed that mean serum ferritin concentration in cases and controls were $95.06 \pm 50.07 \mu \mathrm{g} / 1$ and $45.56 \pm 27.44 \mu \mathrm{g} / 1$ respectively. There was highly significant difference of mean serum ferritin concentration between cases and controls $(p=0.0001)$ (Table - I). The study also showed that mean serum iron concentration in cases was $121.78 \pm 41.93$

$\mu \mathrm{g} / \mathrm{dl}$ and that in controls was $61.04 \pm 24.18$ $\mu \mathrm{g} / \mathrm{dl}$. Mean serum iron concentration was found to be significantly higher $(\mathrm{p}=0.0001)$ (Table - II) in cases compared to that of controls.

Table-I: Comparison of serum ferritin concentration between cases and controls:

\begin{tabular}{ccccc} 
Parameters & $\begin{array}{c}\text { Case }(\mathbf{n}=50) \\
\text { Mean } \pm \text { SD }\end{array}$ & $\begin{array}{c}\text { Control }(\mathbf{n}=50) \\
\text { Mean } \pm \text { SD }\end{array}$ & t value & p value \\
\hline Serum & $95.06 \pm 50.07$ & $45.56 \pm 27.44$ & 6.131 & $0.0001^{* * *}$
\end{tabular} ferritin $(\mu \mathrm{g} / \mathrm{l})$

Range $\quad 12-154 \quad 10-110$

Student's unpaired ' $t$ ' test was done as a test of significance

Table-II: Comparison of serum iron concentration between cases and controls

\begin{tabular}{|c|c|c|c|c|}
\hline \multirow[t]{2}{*}{ Parameters } & \multicolumn{2}{|c|}{ s Case $(n=50)$ Control $(n=50)$} & \multirow[t]{2}{*}{ t value } & \multirow[t]{2}{*}{$\mathrm{p}$ value } \\
\hline & Mean \pm SD & Mean \pm SD & & \\
\hline $\begin{array}{l}\text { Serum } 1 \\
\text { iron }(\mu \mathrm{g} / \mathrm{dl}\end{array}$ & $\begin{array}{l}121.78 \pm 41.93 \\
\text { dl) }\end{array}$ & $61.04 \pm 24.18$ & 8.873 & $0.0001 * *$ \\
\hline Range & $23-154$ & $22-122$ & & \\
\hline
\end{tabular}

Student's unpaired 't' test was done as a test of significance

\section{Discussion}

Pre-eclampsia is one of the most important complications of pregnancy that is associated with increased maternal mortality and morbidity ${ }^{10}$. Approximately 50,000 women die each year from this complication worldwide ${ }^{2}$. Numerous studies on etiology and biochemical variables in preeclamptic women have been carried out throughout the world. Among them alteration of iron status is identified as a risk factor for pathogenesis of preeclampsia by some researchers ${ }^{6,7}$. Therefore, the present study has been undertaken to assess the iron status in preeclampsia. There was highly significant difference of mean serum ferritin and mean serum iron concentration between cases and controls. The result of the present study were in 
accordance with other similar studies like Rayman et al. ${ }^{6}$ Recent study by Siddiqui et al. ${ }^{8}$ also revealed that serum ferritin and serum iron concentration were significantly higher $(p<0.05)$ in preeclamptic women in comparison to normal pregnant women which are similar to the findings of present study. However, Ugwaja et. al. ${ }^{11}$ in their study did not find significant $(p>0.05)$ difference between two groups. This result does not agree with the result of present study. From the above discussion it can be concluded that preeclamptic group had significantly higher level of serum ferritin and serum iron though the levels were within normal reference range in both groups. So It is needed to explore that whether increased level of serum ferritin and serum iron are associated with preeclampsia or not.

In conclusion, the present study revealed presence of significantly higher level of serum ferritin and serum iron in pre-eclamptic group. So elevated serum ferritin and serum iron concentration might play an important role in the etiopathogenosis of preeclampsia.

\section{Acknowledgement:}

The authors would like to thank all the doctors and staff of Department of Biochemistry, Dhaka Medical College, Dhaka for their sincere help in conducting this study.

\section{References}

1. Cunningham FG, Macdonald DC, Gant NF, Leveno KJ, Gilstrap LC. Hypertensive disorders in pregnancy, Williams Obstetrics 20th Ed: London. Appleton \& Lange. 1997: p. 568.

2. Dulay L. Maternal mortality associated with hypertensive disorders of pregnancy in Africa, Asia, Latin America and Caribbean, Br J Obstet Gynecol 1992; 99: 547 - 53.
3. Rashid KM, Rahman M, Hyder S. eds MCH and reproductive health, Textbook of Community Medicine and Public Health 4th Ed: Dhaka. RHM Publishers. 2007: p. 155.

4. Dekker GA, Sibai BM. Etiology and pathogenesis of preeclampsia: Current concepts, Am J Obstet Gynecol 1998; 179: 1359 - 75.

5. Robert JM, Taylor RN, Musci TJ, Rodgers GM, Hubel CA, McLaughlin MK. Preeclampsia: An endothelial cell disorder, Am J Obstet Gynecol 1989; 161: 1025 - 34.

6. Rayman MP, Barlis J, Evans RW, Redman CWG, King LJ. Abnormal iron parameters in pregnancy syndrome preeclampsia, Am J Obstet Gynecol 2002; 187: 412 - 18.

7. Taheripanah R, Farkush PB. Relation between serum iron and iron parameters with preeclampsia, Journal of Fam \& Reprod Health 2007; 1: 87 - 90.

8. Siddiqui IA, Jaleel A, Kadri H.M.F.A., Saeed WA, Tamimi W. Iron status parameters in preeclampsia, Arch Gynecol Obstet 2010: 1728 - 32.

9. Adamson JW. Iron deficiency and other hypoproliferative anaemias, In: Oennis LK, Eugene B, Anthony SF, Stephen LH, Dan LL \& Jameson JL. eds Harrison's Principles of Internal Medicine 16th Ed: New York. Mcgraw Hill. 2005: pp. 586 - 7.

10. Berg CJ, Atrash HK, Koonin LM, Tucker M. Pregnancy related mortality in United States (1987 1990), Obstet Gynecol 1996; 88: 161.

11. Ugwaja EI, Ejikeme BN, Ugwu NC, Obeka NC. Comparison of plasma copper, iron and zinc levels in hypertensive and non-hypertensive pregnant women in Abakaliki, South Eastern Nigeria. Pak J Nutr 2010; 9: 1136 - 40. 